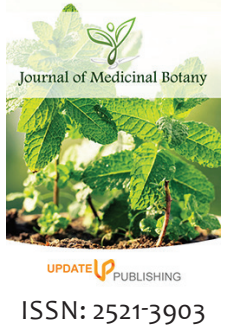

Received : April 20, 2021

Accepted : December 26, 2021

Accepted : December 28, 2021

Published : December 30, 2021

*Corresponding Author:

Raghava S. Boddupalli

Email: raghavazboddupalli@

gmail.com

\section{A review on most important poisonous plants and their medicinal properties}

\author{
Raghava S. Boddupalli* \\ Retired Scientist, \# 19, Sri Purushottama Nilayam, $16^{\text {th }}$ Cross Road, $5^{\text {th }}$ Main Road, N.N. Farm, Sanjayanagar, \\ Bangalore - 560094, Karnataka, India.
}

\begin{abstract}
Plants produce poisons to protect themselves, sometimes at levels toxic enough to kill human or livestock. Through trial and error, our forebears established which plants were edible and which caused harm. They then avoided the harmful species or in some cases also knowingly used them as weapons to kill rivals, criminals and animals, or as drugs to evoke hallucinations or subject victims to trial by ordeal. While knowledge of poisonous plants may have been lost among the majority of us who now buy our food in shops, scientific understanding of plant toxins and their effects has increased greatly. Poisonous plants which cause serious problems or even death are considered as 'Plant Biological Weapons'. In this review article, 12 poisonous angiosperm plant species belonging to eight different families are discussed. The general characteristics of plant species, its distribution, etymology, its toxic nature, symptoms and medicinal uses/ properties are systematically deliberated.
\end{abstract}

KEYWORDS: Poisonous plants, medicinal properties, phytochemical constituents, forensic toxicology, biological weapons

\section{INTRODUCTION}

Plants cannot run away from their predators, hence evolved so many mechanisms to escape from predators by means of physical, morphological and chemicals. Poisonous plants are a group of plants that yield phyto-constituents, which exert harmful causes or effect death either presently or by purpose of cumulative activity of the toxic activity due to presence of known or unknown phytochemical principles in it and not by mechanical activity (Chopra et al., 1949; Kingsbury, 1994). These poisonous plants can be distinguished as highly toxic or lethal, psychotropic/psychoactive or causing allergic reactions to human beings or animals. The category of poisonous plants can be divided into following groups: (1) Poisonous wild plants - herbs, shrubs and trees and (2) Poisonous cultivated plants - grown as house plants, flower garden plants, vegetable garden plants and as ornamental plants.

Most of the plants are capable of producing different kind of chemicals when they come in contact with other beings, especially humans and animals. The poisonous quality of complete plant or any plant part may be due to production of phytotoxic substances namely, glycosides, phenolic toxicants, resins, tannins, saponins, proteins, amino acids, amines, mycotoxins, alkaloids, carbohydrates, chelating poisons, metals, ketones, essential oil, picrotoxins toxalbumins, etc. Several of which are detrimental to man and animal life, at least under certain conditions and each group of poison acts differently. Literally thousands of plants contain various quantities of poisonous chemicals. It is difficult for several people to identify these poisonous plants in nature. Particularly women and children are prone to be victimized by eating poisonous plants accidently. The poisonous plant parts may be root, leaves, stem, latex, stem bark, fruit and seed or even whole plant (Chopra et al., 1949; Kingsbury, 1994). Sometimes a single plant species possesses both activities as poisonous and therapeutic value. Poisoning can occur in the following ways: (a) Eating or touching leaves or any other plant parts, (b) ingesting berries, blossoms, roots, fruits or seeds, (c) skin contact with sap or juices, (d) eating soil (in case of children), (e) drinking water from plant tray (children or pets) and (f) unknowingly plucking the plant parts using bear hands by villagers and amateur plant collectors. The World Health Organization (WHO) in 2008 defined poison as "Poisoning is when cells are injured or destroyed by the inhalation, ingestion, injection or absorption of a toxic substance. Key factors that predict the severity and outcome of poisoning are the nature, dose, formulation and route of exposure of the poison; co-exposure to other poisons; state of nutrition of the child or (fasting status); age and pre-existing health conditions".

Poisonous plants which cause serious problems or even death are considered as 'Plant Biological Weapons (PBW)'. These are

Copyright: (-) The authors. This article is open access and licensed under the terms of the Creative Commons Attribution License (http://creativecommons.org/licenses/by/4.0/) which permits unrestricted, use, distribution and reproduction in any medium, or format for any purpose, even commercially provided the work is properly cited. Attribution - You must give appropriate credit, provide a link to the license, and indicate if changes were made. 
the first choice of professional poisoners in toxicological crime because of their easy availability and having no cost. These plant derived naturally occurring plant biological weapons were also used by criminals in burglary, rape and murder cases. Khajja et al. (2011) reported that in India, there are so many cases where criminals use these products by mixing in food material or/and contact to victim's body in the buses/trains. The toxic constituents of many of such plants need to be properly recorded to develop a prefect database to be utilized in forensic analysis and identification of specific causal agents (Kajja et al., 2011). Gupta and Sharma (2017) reported an updated account of forensically important Indian traditional toxic plants and their chemical ingredients commonly used by the criminals to commit different crimes.

Toxic medicinal plants can be defined as any plant that in one or more of its organs contains toxin that can induce adverse side effects in animal/humans upon consumption or administration for therapeutic purposes. The use of plants is currently not regulated in most countries, resulting in a serious danger of misadministration of toxic plants. The potential toxic effects following prolonged use of some of the popular medicinal plants are to be scientifically investigated. Scientific evidence to recommend the use of these poisonous plants in its natural form for any condition is insufficient, but some of its components, which are purified and used for several medicinal purposes. A study aiming to present a general examination of some plants associated with poisoning but used for their medicinal purposes is presented by Rita (2018). The Ayurveda, Siddha and Unani have been in existence in India since ancient times. Siddha system is capable of treating all types of diseases by using poisonous plants. These plants comprise the third largest category of poisons known around the world. Only some poisonous plants are used for medicinal purposes. According to WHO, $80 \%$ of the population of developing countries depends on plant drugs for regular source of medicines.

The objective of this review article is to provide information on the selected poisonous plants' etymology, toxic compounds present and symptoms upon ingestion. Also, their medicinal uses are highlighted.

\section{DISCUSSION}

Similar to animals, there are some plants which have evolved themselves to have both physical and chemical defense mechanisms that help them escape their predators which are most often than not humans. Here below are some of the most dangerous, highly poisonous angiosperm plants in the world which one should be aware of for their safety. In this review article, 12 plants are selected based on their toxicity. The chemical constituents along with the effects/symptoms and the medicinal properties of the poison is provided for discussion. Poisonous plants and their toxic nature of plant parts, chemical constituents and medicinal properties are highlighted in the Table 1. Also, representative images of each toxic plant and its parts are depicted in the Figure 1 as a pictorial guide for readers' awareness and identification.

\section{A. Indian liquorice - Abrus precatorius L. - Fabaceae}

Abrus precatorius commonly known as crab's eye, Indian bead, jequirty, gunji, rosary pea, precatory pea or bean and Indian licorice. This legume species is found in tropical and subtropical regions. The deciduous creeper is native to tropical Asia and Australia. It grows in most warm, humid climates all over the world such as in the Caribbean Islands and Florida.

It is a perennial climbing shrub, twines around trees, shrubs, and hedges; Leaves stipulate, Leaflets 12-16 pairs, Raceme shorter than leaves; Flowers fascicled, few, calyx sparsely pubescent; Corolla whitish-pink; Pod thick, hard, wrinkled; Seeds adhere to pods, brilliant red, with a black base and a white basal hilum, no fracture lines. The seeds of Abrus precatorius have been used throughout history in a variety of roles. Due to their uniform size and weight, they are known as ratti, and were used as weights for weighing gold and silver (Figure la and b).

\section{Etymology}

The genus name Abrus in Latin means 'graceful' and it refers to its beautiful flowers. The species name precatorius expresses 'entreaty' or supplication and is prayerful. Earlier, these seeds were imported from India for use in Europe for making rosaries.

\section{Toxicity}

Plant is toxic due to the presence of abrin, which is a dimer containing two protein subunits A and B. Protein B facilitates abrin entry into a cell by bonding to certain transport proteins on cell membranes. Protein A prevents protein synthesis by inactivating $26 \mathrm{~S}$ subunit of the ribosome. One molecule of abrin inactivates 1500 ribosome per second.

\section{Symptoms}

Symptoms may be rapid or delayed to 1-2 days. Ingestion of a single seed when well chewed can be fatal to both adults and children. The toxin is released only after breaking of seeds. Infusion of seed extracts can cause eye damage, conjunctivitis and even blindness after contact. The major symptoms of poisoning are acute gastroenteritis with nausea, vomiting and diarrhoea leading to dehydration, convulsions, and shock. Dehydration, as well as direct toxicity on the kidneys, could result in oliguria that might progress to death in uraemia (Inchem, 2004). If the de-hulled seed is contacted with blood or nerves it causes immediate death.

During inhalation symptoms like breathing difficulty, fever, cough, nausea and tightness in the chest can be observed. Upon inhalation, heavy sweating followed by fluid building up in the lungs (pulmonary edema) is detected. This would make breathing even more difficult, and the skin might turn blue. During ingestion symptoms such as vomiting and diarrhea, severe dehydration, low blood pressure, blood in urine, seizures and hallucination can be witnessed. Within several days, the person's liver, spleen, and kidneys might stop working and 
Table 1: Poisonous plants, toxic parts, chemical constituents and medicinal properties

\begin{tabular}{|c|c|c|c|c|}
\hline S. No & Plant Name & Toxic Parts & Chemical Constituents & Medicinal Property \\
\hline 1 & $\begin{array}{l}\text { Abrus precatorius } \\
\text { (Fabaceae) }\end{array}$ & $\begin{array}{l}\text { Seeds, Leaves } \\
\text { Aerial parts }\end{array}$ & Abrin, Abrine and Abrasine & $\begin{array}{l}\text { Anticancer, Antibacterial, Antifungal } \\
\text { Antimigraine, } \\
\text { Bronchodilator } \\
\text { Antioxidative activity }\end{array}$ \\
\hline 2 & $\begin{array}{l}\text { Aconitum napellus } \\
\text { (Ranunculaceae) }\end{array}$ & $\begin{array}{l}\text { All parts especially } \\
\text { dried tuberous root }\end{array}$ & $\begin{array}{l}\text { Aconitine, Pseudo Aconite, } \\
\text { Indaconitine Bhikhaconitine, } \\
\text { Picraconitine, } \\
\text { and Aconine }\end{array}$ & --- \\
\hline 3 & $\begin{array}{l}\text { Ageratina altissima } \\
\text { (Asteraceae) }\end{array}$ & Aerial plant parts & Tremetol or Tremetone & $\begin{array}{l}\text { Diaphoretic, Diuretic, Febrifuge, Stimulant and } \\
\text { tonic, snakebites }\end{array}$ \\
\hline 4 & $\begin{array}{l}\text { Argemone mexicana } \\
\text { (Papaveraceae) }\end{array}$ & $\begin{array}{l}\text { All parts especially } \\
\text { seeds }\end{array}$ & $\begin{array}{l}\text { Berberine, Protopine, } \\
\text { Sanguinarine and } \\
\text { Dihydro-Sangunarine }\end{array}$ & $\begin{array}{l}\text { Jaundice therapy } \\
\text { Laxative }\end{array}$ \\
\hline 5 & $\begin{array}{l}\text { Atropa belladonna } \\
\text { (Solanaceae) }\end{array}$ & All parts & $\begin{array}{l}\text { Atropine, Scopolamine, } \\
\text { Hyoscyamine, and } \\
\text { Belladonnine }\end{array}$ & $\begin{array}{l}\text { Sedative for bronchial spasms, Belladonna plasters } \\
\text { and ointments for nerve pains. }\end{array}$ \\
\hline 6 & $\begin{array}{l}\text { Cascabela thevetia } \\
\text { (Apocynaceae) }\end{array}$ & $\begin{array}{l}\text { All parts especially } \\
\text { leaves and fruits }\end{array}$ & $\begin{array}{l}\text { Cerberin, Cerberoside, } \\
\text { Odollin, Odolotoxin, } \\
\text { Thevetin and Cerapain }\end{array}$ & Antifungal, Antibacterial and Antitermite \\
\hline 7 & $\begin{array}{l}\text { Cerbera odollum } \\
\text { (Apocynaceae) }\end{array}$ & Fruit and seed & $\begin{array}{l}\text { Thevetin, Thevetoxin, } \\
\text { Nerifolin, Peruvoside, } \\
\text { Ruvoside and Cerberin }\end{array}$ & $\begin{array}{l}\text { Purgative, Anticancer, Antibacterial, Antifungal, } \\
\text { diuretic, cytotoxic, Antitermite, and Antioxidant }\end{array}$ \\
\hline 8 & $\begin{array}{l}\text { Chelidonium majus } \\
\text { (Papaveraceae) }\end{array}$ & All parts and latex & $\begin{array}{l}\text { Alkaloids, including chelidonine, } \\
\text { chelerythrine, chelidocystatin, coptisine, } \\
\text { sanguinarine, berberine, and sparteine }\end{array}$ & $\begin{array}{l}\text { Mild sedative, antispasmodic in bronchitis, } \\
\text { whooping cough, asthma, jaundice, gallstones, and } \\
\text { gallbladder pain. Latex is used topically for warts, } \\
\text { ringworms, and corns. }\end{array}$ \\
\hline 9 & Cicuta virosa (Apiaceae) & All parts & Cicutoxin and Oenanthotoxin & $\begin{array}{l}\text { Root is analgesic, antispasmodic, emetic, } \\
\text { galactofuge and sedative }\end{array}$ \\
\hline 10 & $\begin{array}{l}\text { Conium maculatum } \\
\text { (Apiaceae) }\end{array}$ & All parts & $\begin{array}{l}\text { Coniine and } \\
\text { Methyl Coniine }\end{array}$ & --- \\
\hline 11 & $\begin{array}{l}\text { Datura stramonium } \\
\text { (Solanaceae) }\end{array}$ & $\begin{array}{l}\text { All parts especially } \\
\text { seeds and fruit }\end{array}$ & $\begin{array}{l}\text { Atropine, Hyoscyamine, Hyscine } \\
\text { and Dutarin }\end{array}$ & $\begin{array}{l}\text { Analgesic, Anthelmintic, Anti-inflammatory. The } \\
\text { juice of its fruit is applied to the scalp, to treat } \\
\text { dandruff and falling hair }\end{array}$ \\
\hline 12 & $\begin{array}{l}\text { Dioscorea communis } \\
\text { (Dioscoreaceae) }\end{array}$ & $\begin{array}{l}\text { All parts especially } \\
\text { fruits and rhizomes }\end{array}$ & Phenanthrenes, Raphides and Histamines & Anti-inflammatory \\
\hline
\end{tabular}

the person could die. The fatal dose of abrin is approximately 75 times smaller than the fatal dose of ricin. Abrin can kill with a circulating amount of less than $3.0 \mathrm{mg}$. Abrin has an estimated human fatal dose of $0.1-1.0 \mu \mathrm{g} / \mathrm{kg}$. It is as poisonous as cobra bight. Ingesting the intact seeds typically results in no clinical findings, as they pass through the gastrointestinal tract due to their hard shell (Jang et al., 2010).

\section{Medicinal properties}

Ethno-botanically A. precatorius is used to treat tetanus, and to prevent rabies. The plant is used in some traditional medicine to treat scratches and sores and wounds caused by dogs, cats and mice, and are also used with other ingredients to treat leucoderma. The leaves of the herb are used to cure fever, cough and cold. The roots are used to treat jaundice and haemoglobinuric bile. Paste of roots is used to cure abdominal pains, tumors and also for abortion. Root is chewed as a snake bite remedy.

\section{B. Aconite - Aconitum napellus L. - Ranunculaceae}

Aconitum napellus is commonly called monk's-hood, garden monkshood, aconite or wolfsbane. It is a species of highly toxic flowering plant belongs to family Ranunculaceae. The species is native and endemic to western and central Europe.
It is an herbaceous, tuberous-rooted perennial plant growing to one meter tall, with hairless stems and leaves. Flowers on terminal racemes of hooded are dark purple to bluish-purple, narrow oblong helmet-shaped, $1-2 \mathrm{~cm}$ long. The plant's stalks are loaded with purple flower and every blossom is shaped like a hood of a medieval monk making them distinct. Plants native to Asia and North America formerly listed as A. napellus are now regarded as separate species. The plant is extremely poisonous in both ingestion and skin contact (Figure ld and e).

\section{Etymology}

Ancient popular etymology connected the name in part to the adjective akonitós, which means 'invincible' and in part to the name of the hill Akonitos in Pontus. The Latin species name napellus is derived from nápus, which means 'tuber' and refers to the shape of the roots.

\section{Toxicity}

The plants contain aconitine and other alkaloids which are highly toxic and are classified as neurotoxins and cardiotoxins. Aconitine is a potent neurotoxin that opens tetrodotoxin sensitive sodium channels. It increases influx of sodium through these channels and delays repolarization, thus increasing 

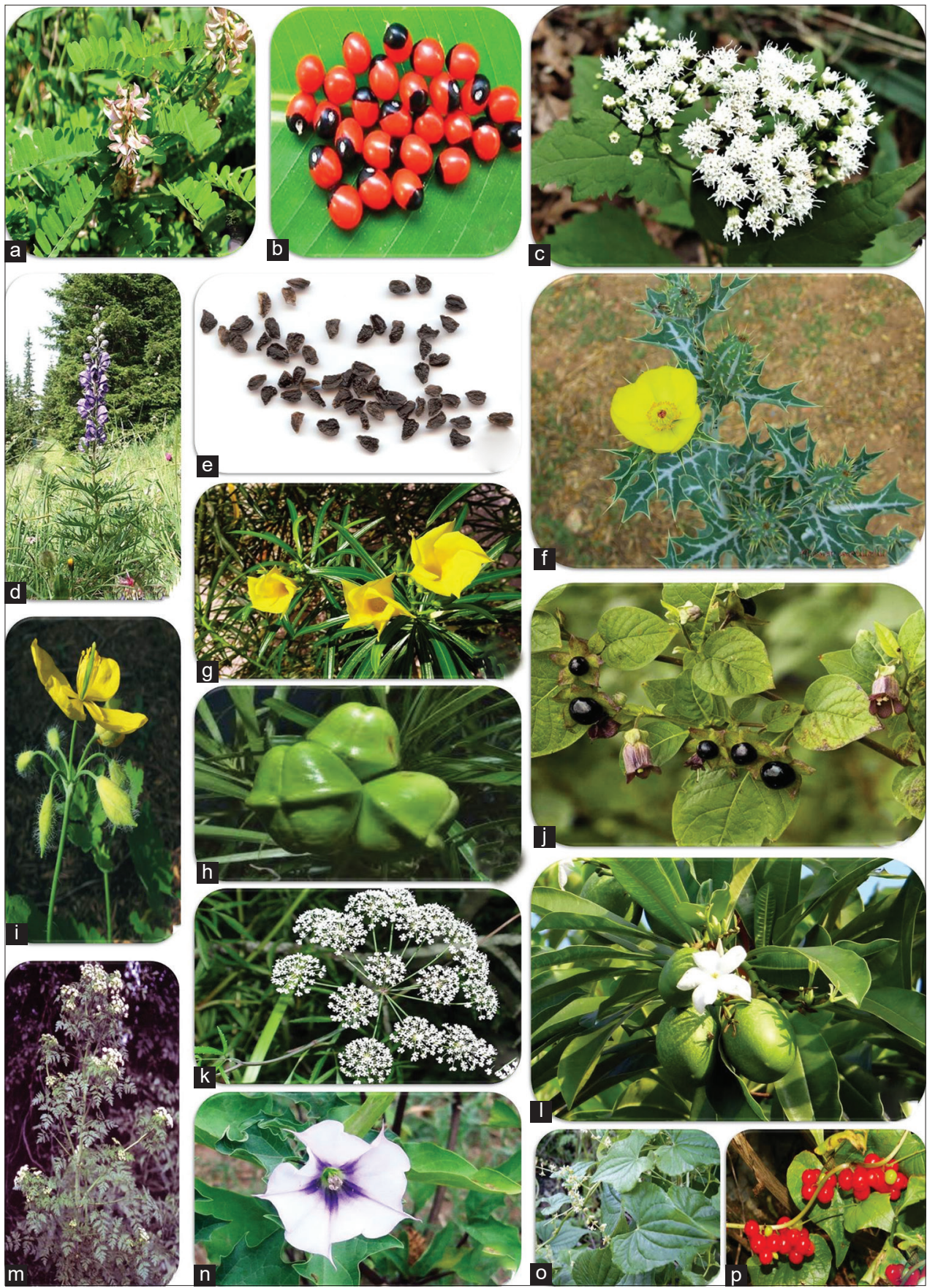

Figure 1: Twelve most important poisonous plants and their toxic parts - (a) Abrus precatorius (Indian liquorice) plant, (b) Seeds; (c) Ageratina altissima (White snakeroot) in flowering; (d) Aconitum napellus (Aconite) in flowering, (e) Seeds; (f) Argemone mexicana (Mexican poppy) in flowering; (g) Cascabela thevetia (Yellow oleander) in flowering, (h) Fruits; (i) Chelidonium majus (Greater celandine) with flowers and fruits; (j) Atropa belladonna (Belladonna) with flowers and fruits; (k) Cicuta virosa (Water hemlock) in flowering; (I) Cerbera odollum (Ordeal tree) with flowers and fruits; (m) Conium maculatum (Poison hemlock) in flowering; (n) Datura stramonium (Jimsonweed) in flowering; (o) Dioscorea communis (Black bryony) climber, (p) Fruits

excitability and promoting ventricular dysrhythmias. During the ancient Roman period of European history, the plant was often used to eliminate criminals and enemies, and by the end of the period it was banned and anyone growing A. napellus could have been legally sentenced to death (Roberts \& Wink, 1998). Aconites have been used more recently in murder plots. They contain the chemical alkaloids aconitine, mesaconitine, hypaconitine and jesaconitine, which are highly toxic.

\section{Symptoms}

Consumption of this plant could lead to serious complications including burning, diarrhoea and vomiting. It could also lead to variations in blood pressure, heart irregularities and coma. Marked symptoms may appear almost immediately, usually not later than one hour, and "with large doses, death is almost instantaneous". Death usually occurs within two to six hours in 
fatal poisoning (20 to $40 \mathrm{~mL}$ of tincture may prove fatal). The initial signs are gastrointestinal including nausea, vomiting, and diarrhea. This is followed by a sensation of burning, tingling, and numbness in the mouth and face, and of burning in the abdomen.

\section{White Snakeroot - Ageratina altissima (L.) King \& H.E. Robins - Asteraceae}

The plant is native to eastern and central regions of North America commonly known as snakeroot, white snakeroot, richweed or white sanicle is a poisonous perennial herb and is one of the most dangerous plants in the world.

Plants are upright or sometimes ascending, growing to 1.5 meters tall, producing single or multi-stemmed clumps in mid to late summer and fall. Plants are light green to tan, hairless stems, leaves opposite, broadly lanceolate, serrate-crenate, hairless; flowers are in panicle flower-heads, fragrant, numerous and clean white color after blooming; small seeds with fluffy white tails are released to blow in the wind. The root system consists of spreading rhizomes and shallow fibrous roots. This plant can spread vegetatively by means of its rhizomes, or it can reseed itself into new areas. The species is adaptive to different growing conditions; it is found in woods and brush thickets and also in shady areas with open bare ground, and can be weedy in shady landscapes and hedgerows (Figure lc).

\section{Etymology}

Ageratina is derived from Greek meaning 'un-aging', in reference to the flowers keeping their color for a long time. This name was used by Dioscorides for a number of different plants. Altissima means 'the tallest', and probably indicates that this is the tallest species in its genus (Gledhill, 2008).

\section{Toxicity}

White snakeroot plant contains the toxin tremetol or trementone. When the plants are consumed by cattle, the meat and milk become contaminated with the toxin. This contaminated milk or meat containing the toxin is consumed, the toxin is transferred to human body. If consumed in large enough quantities, it can cause tremetol poisoning in humans. The poisoning is also called milk sickness, as humans often ingested the toxin by drinking the milk of cows that had eaten snakeroot (Niering \& Olmstead, 1985). Back in the $19^{\text {th }}$ century, more than 1000 people died of milk sickness and it is widely reported that Nancy Hanks, mother of Abraham Lincoln, dies of milk sickness. Although $80 \%$ of the plant's toxin, tremetone, decreases after being dried and stored away for five years, its toxicity properties remain the same (Davis et al., 2018).

\section{Symptoms}

The milk sickness and its symptoms can include loss of appetite, nausea, abdominal discomfort, weakness, reddened tongue and mucous membranes and also abnormal acidity in the blood.

\section{Medicinal Properties}

Despite its toxicity, several Native American tribes found medicinal uses for white snakeroot, often using the root, but other plant parts as well. Some sources say that a poultice to treat snakebites was made from the root, resulting in the common name, white snakeroot. Root tea has been used to treat diarrhea, kidney stones, and fever.

\section{Mexican Poppy - Argemone mexicana L. - Papaveraceae}

Argemone mexicana commonly known as mexican poppy, mexican prickly poppy, flowering thistle, cardo or cardosanto is a species of poppy found in Mexico and now widely naturalized in many parts of the world. It is generally found in road side and also in waste places.

It is an annual herb, growing up to $150 \mathrm{~cm}$ with a slightly branched tap root. Its stem is branched and usually extremely prickly. Leaves are thistle-like and alternate, without leaf stalks (petioles), toothed (serrate) and the margins are spiny. The grey-white veins stand out against the bluish-green upper leaf surface. Flowers are at the tips of the branches (are terminal) and solitary, yellow and of $2.5-5.0 \mathrm{~cm}$ diameter. Fruit is a prickly oblong or egg-shaped (ovoid) capsule. Seeds are very numerous, nearly spherical. An extremely hardy pioneer plant, it is tolerant of drought and poor soil, often being the only cover on new road cuttings or verges. It has bright yellow latex. It is poisonous to grazing animals, and it is rarely eaten, but it has been used medicinally by many peoples, including those in its native area, as well as the natives of the western United States of America, parts of Mexico and many parts of India (Figure lf).

\section{Etymology}

Argemone is from the Greek argena, meaning 'cataract of the eye', and was the name used in the first century AD by the classical authors Dioscorides (AD 40-90) and Pliny (AD 23-79) for some spiny poppies, the juice of which was supposedly a cure for cataract. The species epithet mexicana combines Mexico with the Latin suffix ana, belonging to, suggesting the country of origin (Parsons \& Cuthbertson, 1992).

\section{Toxicity}

Entire plant and especially the seed of this weed are poisonous. Argemone oil contain two alkaloids namely sanguinarine and Dihydrosenguinarine. Four quaternary isoquinoline alkaloids, dehydrocorydalmine, jatrorrhizine, columbamine, and oxyberberine, have been isolated from the whole plant of Argemone mexicana (Singh et al., 2010). These seeds resemble the seeds of mustard. As a result, mustard can be adulterated by argemone seeds, rendering it poisonous. Several significant instances of katkar poisoning have been reported in India, Fiji, South Africa and other countries. The last major outbreak in India occurred in 1998. One percent (1\%) adulteration of mustard oil by argemone oil has been shown to cause clinical disease. In India, odollum oil is mixed with sunflower oil and 
sesame oil to increase the quantity, but this adulteration causes health disorders and renowned brands display 'no argemone oil' to qualify purity. Katkar oil poisoning causes epidemic dropsy, with symptoms including extreme swelling, particularly of the legs.

\section{Symptoms}

It will not cause immediate death but slowly it creates many health problems that may lead to death. Wheat flour contaminated with Argemone seeds cause acute inflammation of gastro-intestinal tract. Several epidemics occurred in India due to argemone oil poisoning. People were affected with dropsy, glaucoma followed by blindness. Argemone poisoning cause non inflammatory bilateral edema of legs associated with diarrhoea, cardiac failure and sometimes even death. It also produces abortion, vomiting anaemia and alopecia. Sometimes the oil from the Argemone seeds is used to adulterate edible oils especially mustard oil and sesamum oils. This plant is smoked as a marijuana substitute.

\section{Medicinal Properties}

The Seri of Sonora, Mexico uses the entire plant both fresh and dried. An infusion is made to relieve kidney pain, to help expel a torn placenta, and in general to help cleanse the body postnatally. When the Spanish arrived in Sonora they added this plant to their pharmacopeia and called it cardosanto, which should not be mistranslated to blessed thistle (Cnicus benedictus). The seeds are taken as a laxative. An Argemone mexicana tea is used by traditional healers in Mali to treat malaria (Willcox et al., 2007). This has many medicinal benefits. Traditionally, the flowers are soaked in water overnight and cleaning the eyes with this water helps improve eyesight. The juice of these leaves helps in treating various skin conditions. This is also used for treating scorpion and snake bites. The dried plant powder used as tea or when mixed with honey and consumed, it helps with cough, asthma and improves overall respiratory health. The roots are cleaned, soaked, ground and consumed to eliminate any worms in the intestines. The dry powder is used to brush teeth to prevent any gum problems. In the traditional medicine of India, the yellow sap of A. mexicana and the whole plant are also used in jaundice therapy (Tewari et al., 2017).

\section{E. Belladonna - Atropa belladonna L. - Solanaceae}

Atropa belladonna, commonly known as belladonna or deadly nightshade, is a poisonous perennial herbaceous plant. The other common names include divale, dwale, banewort, devil's berries, death cherries, beautiful death, devil's herb, great morel and dwayberry. It is native to Europe, North Africa, and Western Asia. Its distribution extends from Great Britain in the west to western Ukraine and the Iranian province of Gilan in the east. It is also naturalized or introduced in some parts of Canada and the United States.

Atropa belladonna is a branching herbaceous perennial rhizomatous hemi-cryptophyte, often growing as a subshrub from a fleshy rootstock. Plants grow to 2.0 meters tall with ovate leaves $18 \mathrm{~cm}$ long. The bell-shaped flowers are dull purple with green tinges and faintly scented. The fruits are berries, which are green, ripening to a shiny black, and approximately $1.5 \mathrm{~cm}$ in diameter. The berries are sweet and are consumed by animals that disperse the seeds in their droppings and they contain toxic alkaloids (Figure lij).

\section{Etymology}

The name Atropa belladonna was published by Carolus Linnaeus in Species Plantarum in 1753. Atropa is derived from the name of the Greek goddess Atropos ('she who may not be turned aside' i.e. 'the inflexible' or 'the implacable') - one of the three Greek fates or destinies who would determine the course of a man's life by the weaving of threads that symbolized his birth, the events in his life, and finally his death, with Atropos cutting these threads to mark the last. The name belladonna originated from the Italian language, meaning 'beautiful lady' making either from its usage as a cosmetic to beautify pallid skin or more probably, from its usage to increase the pupil size in women.

\section{Toxicity}

Belladonna is one of the most toxic plants known and its use by mouth increases risk in numerous clinical conditions, such as complications of pregnancy, cardiovascular diseases, gastrointestinal disorders, and psychiatric disorders, among others. All parts of the plant contain tropane alkaloids (Ulbricht et al., 2004). Leaves reach maximal alkaloid content when the plant is budding and flowering, roots are most poisonous in the end of the plant's vegetation period (Raetsch, 2005).

\section{Symptoms}

The active agents in belladonna, atropine, hyoscine (scopolamine), and hyoscyamine, have anticholinergic properties. The symptoms of belladonna poisoning include dilated pupils, sensitivity to light, blurred vision, tachycardia, loss of balance, staggering, headache, rash, flushing, severely dry mouth and throat, slurred speech, urinary retention, constipation, confusion, hallucinations, delirium, and convulsions (Lee, 2007). A. belladonna berries were mistaken for blueberries by an adult woman and she ate six berries that were resulted in severe anticholinergic syndrome (Mateo et al., 2009). The plant's deadly symptoms are caused by atropine's disruption of the parasympathetic nervous system's ability to regulate involuntary activities, such as sweating, breathing, and heart rate. The antidote for belladonna poisoning is an anticholinesterase (such as physostigmine or pilocarpine), the same as for atropine.

Atropa belladonna is also toxic to many domestic animals, causing narcosis and paralysis. However, cattle and rabbits eat the plant seemingly without suffering harmful effects (Lee 2007). In humans, its anticholinergic properties will cause the disruption of cognitive capacities, such as memory and learning. 


\section{Medicinal Properties}

Though widely regarded as unsafe, belladonna is taken by mouth as a sedative, to stop bronchial spasms in asthma and whooping cough, and as a cold and hay fever remedy. It is also used for Parkinson's disease, colic, inflammatory bowel disease, motion sickness, and as a painkiller. The purified product of l-atropine, which was purified from belladonna in the 1830s, has accepted medical uses (Lee, 2007). Belladonna is used in ointments that are applied to the skin for joint pain, pain along the sciatic nerve, and general nerve pain (Harrison, 1872). Belladonna is also used in plasters (medicine-filled gauze applied to the skin).

\section{F. Yellow oleander - Cascabela thevetia (L.) Lippold - Apocynaceae}

Cascabela thevetia is a small poisonous tree native throughout Mexico and in Central America. The tree is commonly known as yellow oleander, bestill tree, lucky nut (West Indies), Kaneru (Sinhala) and Manjal arali (Tamil). The tree produces yellow, orange, white flowers. It is cultivated in gardens, temples and also found in open forests. It grows occasionally on plains up to $1400 \mathrm{~m}$, in wasteland. It is mostly grown as live fence.

Cascabela thevetia is an evergreen tropical shrub or small tree. Its leaves are willow-like, linear-lanceolate, and glossy green in color. They are covered in waxy coating to reduce water loss (typical of oleanders). Its stem is green turning silver/gray as it ages. Flowers are long funnel-shaped, fragrant, and yellow in terminal clusters. Its fruit is deep red-black in color encasing a large seed (Figure lg and h).

\section{Etymology}

'Cascabel', 'cascavel' or 'cascabela' is Spanish for a small bell, a snake's rattle or a rattlesnake itself (Quattrocchi, 1999). The allusion may also be to the plant's toxicity comparable to the venom of a rattlesnake. The specific name 'thevetia' commemorates André de Thevet (1516 -1590), a French Franciscan priest and explorer, who explored Brazil.

\section{Toxicity}

The main toxins are the cardenolides called thevetin A and thevetin $\mathrm{B}$; others include peruvoside, neriifolin, thevitoxin and ruvoside glycosides (Bose et al., 1999; Kohls et al., 2012). These cardenolides are not destroyed by drying or heating and they are very similar to digoxin compound. They produce gastric and cardiotoxic effects. Antidotes for treatment include atropine and digoxin immune fabs (antibodies) and treatment may include oral administration of activated charcoal (Roberts et al., 2006; Rajapakse, 2009; Bandara et al., 2010). Ovine polyclonal anti-digitoxin Fab fragment antibody (DigiTAb; Therapeutic Antibodies Inc.) can be used to treat Cascabela thevetia poisoning, but for many countries the cost is prohibitive (Eddleston et al., 2000).

A few bird species are however known to feed on them without any ill effects. These include the sunbirds, Asian koel, red- whiskered bulbul, white-browed bulbul, red-vented bulbul, brahminy myna, common myna and common grey hornbill (Krishnan, 1952; Neelakantan, 1953; Raj, 1959; Raj, 1963; Rajasingh \& Rajasingh, 1971; Kannan, 1991).

In South India and in Sri Lanka swallowing the seeds of Cascabela thevetia is one of the preferred methods for suicides in villages where they are grown in abundance (Eddleston \& Warrell, 1999). Extracts from C. thevetia are reported to possess anti-spermatogenic activity in rats (Gupta et al., 2011)

\section{Symptoms}

The seed is broken and the cotyledons are consumed for suicide. Consumption of the seed causes gastric and cardiotoxic symptoms. They include nausea, vomiting, heart stimulation, convulsion and finally death. Eating of one seed can cause death of an adult. In villages many people eat it to commit suicide. When survived they suffer from severe ailments.

\section{Medicinal Properties}

Flowers of the plant Cascabela thevetia were reported to possess good medicinal value in traditional system of medicine. Phytochemical investigation of powdered drug revealed the presence of Alkaloids, glycosides, tannins, phenolic compounds, proteins, essential oils, gums, mucilage and fixed oils (Rupesh et al., 2017). The plant's toxins have tested in experiments for uses in biological pest control. Cascabela thevetia seed oil was used to make a 'paint' with antifungal, antibacterial and antitermite properties (Kareru et al., 2010).

\section{G. Ordeal Tree - Cerbera odollum Gaertn. - Apocynaceae}

Cerbera odollum commonly known as the ordeal tree, suicide tree, pong-pong, mintolla, and othalam in Malayalam and famentana, kisopo, samanta or tangena in Madagascar and pong-pong, buta-buta, bintaro or nyan in Southeast Asia. The fruits of this tree yield a potent poison that has been used for suicide and murder. It is a species native to India and other parts of southern Asia, growing preferentially in coastal salt swamps and in marshy areas but also grown as a hedge plant between home-compounds (Gaillard et al., 2004).

The tree branchlets are whorled about the trunk, leaves are terminally crowded, with tapering bases, acuminate apices, and entire margins. The plant as a whole yields a milky, white latex. Fruits are green, looks like a small mango, with a green fibrous shell enclosing an ovoid kernel measuring approximately $2.0 \mathrm{~cm}$ $\times 1.5 \mathrm{~cm}$ and consisting of two cross-matching white fleshy halves. On exposure to air, the white kernel turns violet, then dark grey, and ultimately brown, or black (Figure 11).

\section{Toxicity}

All parts of the plant are poisonous. The latex and seeds of the tree contain cardiac glycosides- thevitin compounds. The kernels contain cerberin, a digoxin-type cardenolide and cardiac glycoside 
toxin that blocks the calcium ion channels in heart muscle, causing disruption of the heartbeat, most often fatally. The most common symptom of toxicity in humans was noted to be vomiting. Electrocardiographic abnormalities were noted to be common, the most common being sinus bradycardia. Around half of the patients develop thrombocytopenia. Temporary cardiac pacing has been used in the management, apart from other supportive measures (Menon 2016). The difficulty in detecting cerberin in autopsies and the ability of strong spices to mask its taste makes it an agent of homicide and suicide in India; there were more than 500 cases of fatal Cerbera poisoning between 1989 and 1999 in the southwest Indian state of Kerala (Gaillard et al., 2004).

\section{Symptoms}

A fatal dose of the poison is contained in one kernel, leading to death within 1-2 days. Common symptoms include, burning sensation in mouth, violent vomiting, irregular respiration, headache, irregular heartbeat, coma and eventual death.

\section{Medicinal Properties}

A leaf decoction is added to an aromatic bath after childbirth. The bark, leaves and latex are considered to be emetic and purgative. Studies have suggested anticancer, antinociceptive, antibacterial, antifungal, diuretic, cytotoxic, anti-termite, neuropharmacological, and antioxidant activities are present in this tree (Launert, 1981).

\section{H. Greater Celandine - Chelidonium majus Linn. - Papaveraceae}

Chelidonium majus is commonly known as greater celandine, nipplewort, tetterwort, or simply celandine. It is a perennial herbaceous plant in the poppy family (Papaveraceae). It is one of two species in the genus Chelidonium. The species is native to Europe and western Asia and introduced widely in North America.

Greater celandine is a perennial herb with an erect habit, and reaches $30-120 \mathrm{~cm}$ high. Leaves are pinnate with lobed and wavy margins, up to $30 \mathrm{~cm}$ long. The flowers consist of four yellow petals, each about $18 \mathrm{~mm}$ long, with two sepals. The seeds are small and black, borne in a long, cylindrical capsule. Each has an elaiosome, which attracts ants to disperse the seeds (myrmecochory). The plant exudes a yellow to orange latex or sap when injured (Figure li).

\section{Etymology}

The greater celandine is one of the many species described by the father of taxonomy, Carolus Linnaeus, his Species Plantarum in 1753. According to the Oxford English Dictionary, the name celandine comes from Late Latin celidonia, from earlier Latin chelidonia or chelidonium, and ultimately from Ancient Greek from chelidốn 'swallow', hence the common name 'swallowwort'. Ancient writers said that the flower bloomed when the swallows returned and faded when they left.

\section{Toxicity}

The whole plant is toxic in moderate doses as it contains a range of isoquinoline alkaloids. Its use in herbal medicine requires the correct dose. The main alkaloid present in the herb and root is coptisine. Other alkaloids present include methyl 2'-(7,8-dihydrosanguinarine-8-yl) acetate, allocryptopine, stylopine, protopine, norchelidonine, berberine, chelidonine, sanguinarine, chelerythrine, and 8-hydroxydihydrosanguinarine. Sanguinarine is particularly toxic in rats. Caffeic acid derivatives, such as caffeoylmalic acid, are also present (Hahn \& Nahrstedt, 1993). The characteristic latex also contains proteolytic enzymes and the phytocystatin chelidostatin, a cysteine protease inhibitor (Rogelj et al., 1998). It is a traditional folk remedy against warts in France. The plant is poisonous to chickens. The fresh herb is no longer used officially. No dose-finding studies exist and the reported clinical studies are characterized by a considerable heterogeneity.

\section{Symptoms}

Chelidonium has cough with chest symptoms of the right side, liver affections, and the mental affections that commonly belong to these, violent aggravation from motion. The pains are ameliorated by heat and this extends to the stomach, ameliorated by heat. Mental symptoms ameliorated by eating.

\section{Medicinal properties}

Greater celandine was traditionally used to improve eyesight and in modern times has been used as a mild sedative, and antispasmodic in the treatment of bronchitis, whooping cough, asthma, jaundice, gallstones, and gallbladder pain. The latex is used topically to treat warts, ringworm, and corns. A semisynthetic thiophosphate derivative of alkaloids from C. majus, called Ukrain, has cytotoxic and cytostatic effects on tumor cells.

\section{Water hemlock - Cicuta Virosa L. - Apiaceae}

Cicuta virosa, the cowbane or northern water hemlock, is a highly poisonous species in the world. It is native to northern and central Europe, northern Asia and northwestern North America. It grows in wet meadows, along stream banks and other wet and marshy areas. As the species is highly poisonous to horses, livestock, and humans, the U.S. Department of Agriculture (USDA) has also categorized this species as the most violently toxic plant which grown in North America.

It is a perennial herbaceous plant which grows up to $1-2 \mathrm{~m}$ tall and has small umbrella and green or white coloured flowers. The stems are smooth, branching, swollen at the base, purplestriped, and hollow except for partitions at the junction of the leaves and stem. An oily, yellow liquid oozes from cuts to the stems and roots. This liquid has a rank smell resembling that of parsnips or carrots. The plant may be mistaken for parsnip due to its clusters of white tuberous roots (Figure lk). 


\section{Etymology}

The genus name Cicuta is originated from Latin cicūta meaning 'hemlock; pipe' and the species name virosa also originate from Latin vīrōsus meaning ‘poisonous’ (Figure lm).

\section{Toxicity}

The plant contains cicutoxin, which disrupts the workings of the central nervous system. In humans, cicutoxin rapidly produces symptoms of nausea, emesis and abdominal pain, typically within an hour of ingestion. Poisoning can lead to tremors and seizures. A single bite of the root (which has the highest concentration of cicutoxin) can be sufficient to cause death. In animals the toxic dose and the lethal dose are nearly the same. One gram of water hemlock per kilogram of weight will kill a sheep and 230 grams is sufficient to kill a horse. Due to the rapid onset of symptoms, treatment is usually unsuccessful.

\section{Symptoms}

Poisoning from this plant could result in seizures with intermittent relaxation, rolling of eyes and other behavioral abnormalities, turning in circles, twisting of the neck, opening and shutting of mouth, falling down, nausea, vomiting, diarrhoea, hypertension and also coma.

\section{Medicinal properties}

The root is analgesic, antispasmodic, emetic, galactofuge and sedative. The whole plant is highly toxic and is not used in herbal medicine. A homeopathic remedy has been made from this plant in the past.

\section{J. Poison hemlock - Conium maculatum L. - Apiaceae}

Conium maculatum, the hemlock or poison hemlock, is a highly poisonous biennial herbaceous flowering plant in the carrot family Apiaceae. It is native to Europe and North Africa. A hardy plant capable of living in a variety of environments, hemlock is widely naturalized in locations outside its native range, such as parts of North and South America, Australia and West Asia, to which it has been introduced. The vernacular names in the English language are poison hemlock, poison parsley, spotted corobane (rarer forms), carrot fern (Australian English), devil's bread or devil's porridge (Irish English). The plant is often found in poorly drained soil, particularly near streams, ditches and other watery surfaces. It also appears on roadsides, edges of cultivated fields, waste areas, quite damp soil, also on drier rough grassland, roadsides and disturbed ground.

Conium maculatum is a herbaceous biennial flowering plant that grows to 1.5-2.5 meters tall, with a smooth, green, hollow stem, usually spotted or streaked with red or purple on the lower half of the stem. All parts of the plant are hairless (glabrous); the leaves are two- to four-pinnate, finely divided and lacy, overall triangular in shape, up to $50 \mathrm{~cm}$ long and $40 \mathrm{~cm}$ broad. Hemlock's flower is small and white; they are loosely clustered and each flower has five petals. The plant looks like the wild carrot plant (Daucus carota). One can distinguish the two from each other by hemlock's smooth texture, mid-green, quite vivid, color and typical height of large clumps being least 1.5 meters, twice the maximum of wild carrot. Poison hemlock grows in the spring, when much undergrowth is not in flower and may not be in leaf. All plant parts are poisonous.

\section{Etymology}

The genus name Conium originates from the ancient Greek word kốneion means 'hemlock'. This may be related to konas (meaning to whirl), in reference to vertigo, one of the symptoms of ingesting the plant.

\section{Toxicity}

Poison hemlock (Conium maculatum) is a plant that is poisonous for humans and animals. Accidental ingestion of the plant may result in central nervous system depression, respiratory failure, acute rhabdomyolysis, acute renal failure and even death (Konca et al., 2016). Poison hemlock contains coniine and some similar poisonous alkaloids, and is poisonous to all mammals (and many other organisms) that eat it. Intoxication has been reported in cattle, pigs, sheep, goats, donkeys, rabbits, and horses. Ingesting less than a tenth of a gram of coniine, approximately equivalent to six to eight hemlock leaves, can be fatal for adult humans. While every part of the plant is toxic, the highest alkaloid concentration exists in the seeds (Leete, 1994). While hemlock toxicity primarily results from consumption, poisoning can also result from inhalation, and from skin contact. Farmers also need to be careful that the hay fed to animals does not contain hemlock. Poison hemlock is most poisonous in the spring when the concentration of $\gamma$-coniciene (the precursor to other toxins) is at its peak (Peter, 1989). Famous philosopher Socrates died from hemlock poisoning in 399 BC (Reynolds, 2005).

\section{Symptoms}

Ataxia and headache are the symptoms observed in the early stage of poisoning. Increased salivation, tachycardia, and pupillary dilation develop due to the effects of the plant on the autonomic ganglia. Muscle weakness or paralysis, bradycardia, and central nervous system depression may develop in some of the patients due to increased cholinergic stimuli (Ferah et al., 2006). Rhabdomyolysis and acute renal failure have also been reported in some cases as a consequence of Conium maculatum poisoning (Rizzi et al., 1991). Each of these piperidine alkaloids is a kind of peripheral neurotoxin; the neurotoxins show curarelike effects in neuromuscular junctions and create nicotinic effects in the autonomic ganglia (Krenzelok et al., 1996).

\section{K. Jimsonweed - Datura stramonium L. - Solanaceae}

Datura stramonium commonly known as jimsonweed, thorn apple, moon flower, hell's bells, devil's trumpet, devil's weed, devil's snare, tolguacha, Jamestown weed, stinkweed, locoweed, prickly burr, false castor oil plant, and devil's cucumber. It is 
distributed across the world. Jimsonweed is common weed in waste places, which could grow anywhere between 3 to 5 feet tall, while the leaf can grow between 5 to 8 inches.

D. stramonium is a foul-smelling, erect, annual, freely branching herb that forms a bush up to 60 to $150 \mathrm{~cm}$ tall. The root is long, thick, fibrous, and white. The stem is stout, erect, leafy, smooth, and pale yellow-green to reddish purple in color. The leaves are 8 to $20 \mathrm{~cm}$ long, smooth, toothed, soft, and irregularly undulated. The upper surface of the leaves is a darker green, and the bottom is a light green. The trumpet-shaped flowers are fragrant, white to creamy or violet, and 6 to $9 \mathrm{~cm}$ long, The calyx is long and tubular, swollen at the bottom, and sharply angled, surmounted by five sharp teeth. The corolla, which is folded and only partially open, is white, funnel-shaped, and has prominent ribs. The flowers open at night, emitting a pleasant fragrance, and are fed upon by nocturnal moths. Fruit is capsule, egg-shaped 3 to $8 \mathrm{~cm}$ in diameter and either covered with spines or bald. At maturity, it splits into four chambers, each with dozens of small, black seeds (Figure $\ln$ ).

\section{Etymology}

The genus name dhattūra is derived from Sanskrit language (Monier-Williams 1899). The origin of Neo-Latin species name stramonium is unknown, but the name stramonia was used in the $17^{\text {th }}$ century for various Datura species by Carolus Linnaeus.

\section{Toxicity}

Jimsonweed is poisonous which is largely concentrated in the leaf and seeds. All parts of Datura plants contain dangerous levels of the tropane alkaloids atropine, hyoscyamine, and scopolamine, which are classified as deliriants, or anticholinergics (Glatstein et al., 2016). D. stramonium has frequently been employed in traditional medicine to treat a variety of ailments. However, people use it as a recreational drug which causes hallucinations and give a sense of well-being which is called Euphoria. Hence, it has also been used as a hallucinogen (of the anticholinergic/ antimuscarinic, deliriant type), taken entheogenically to cause intense visions. It is unlikely ever to become a major drug of abuse owing to effects upon both mind and body frequently perceived subjectively as highly unpleasant, giving rise to a state of profound and long-lasting disorientation with a potentially fatal outcome. It contains tropane alkaloids which are responsible for the deliriant effects, and may be severely toxic. It is used to make medicines which can treat asthama, cough, influenza, nerve diseases and swine flu (Glatstein et al., 2016).

\section{Symptoms}

Typical symptoms of Datura stramonium poisoning are represented by dry skin and mucosa, flushing, mydriasis, sinus tachycardia, hyperpyrexia, decreased bowel activity, urinary retention, and neurological disorders with ataxia, impaired short-term memory, disorientation, confusion, hallucinations (visual and auditory), psychosis, agitated delirium, seizures, and coma. These symptoms resemble atropine intoxication. The toxins effects could include dry mouth, extreme thirst, seizures, nausea and vomiting, increased heart rate, loss of consciousness, breathing issues and in some cases could lead to death.

\section{Medicinal properties}

The seeds of Datura stramonium are analgesic, anthelmintic and anti-inflammatory and as such, they are used in the treatment of stomach and intestinal pain that results from worm infestation, toothache, and fever from inflammation. The juice of its fruit is applied to the scalp, to treat dandruff and falling hair (Soni et al., 2012).

\section{Black bryony - Dioscorea communis (L.) Caddick \& Wilkin - Dioscoreaceae}

Dioscorea communis is a species of flowering plant in the yam family, Dioscoreaceae, and is commonly known as black bryony, lady's-seal or black bindweed. The species is native and widespread throughout southern and central Europe, northwest Africa and western Asia, from Ireland to the Canary Islands, east to Iran and Crimea. It is a typical plant of the forest understory, from the sea to the mountains, usually in dense woods, but it can also be found in meadows and hedges.

It is a climbing herbaceous plant growing to 2-4 $\mathrm{m}$ tall, with stems that twine anticlockwise. The leaves are spirally arranged, heart-shaped, up to $10 \mathrm{~cm}$ long and $8 \mathrm{~cm}$ broad, with a petiole up to $5 \mathrm{~cm}$ long. It is dioecious, with separate male and female plants. The fruit is a bright red berry, $1 \mathrm{~cm}$ diameter. It's fairly large tuber is, like the rest of the plant, poisonous (Figure lo and p).

\section{Etymology}

The genus name Dioscorea is honoured to Pedanius Dioscorides Anazarbeus (from Anazarbus, city of Cilicia, Asia Minor), famous botanist, and herbalist physician of Greek culture who lived in the first century BC. The name of the species comes from the Latin 'communis', which means common, diffused, known.

\section{Toxicity}

All components of the black bryony plant, including the tubers, are poisonous due to saponin content, so it is not typically used internally. The rhizome of the climber contains phenanthrenes (7-hydroxy-2,3,4,8-tetramethoxyphenanthrene, 2,3,4-trimethoxy-7,8-methylenedioxyphenanthrene, 3-hydroxy2,4,-dimethoxy-7,8-methylenedioxyphenanthrene, 2-hydroxy3,5,7-trimethoxyphenanthrene and 2-hydroxy-3,5,7-trimethoxy9,10-dihydrophenanthrene) [Adriana et al., 2007]. In an another study (Rafael et al., 2011), black-bryony ripened fruits revealed the highest antioxidant properties which are in agreement to its highest concentration in phenolics, flavonoids, ascorbic acid, tocopherols and lycopene. The study on fruits revealed interesting antioxidant properties and bioactive phytochemicals that could provide scientific evidence for their folk uses as antiinflammatory species. 


\section{Symptoms}

Black Bryony is highly poisonous and should not be ingested at all at least the raw plant and its parts. It contains a variety of toxic compounds but it is calcium oxalate crystals (known as raphides) that are mainly responsible for the various symptoms that occur. The berries are attractive to children and they can cause burning and blistering of the mouth and digestive system, resulting in vomiting and diarrhoea. The sap is also an irritant.

\section{Medicinal properties}

Despite serious safety concerns, people take black bryony by mouth to cause vomiting. People also apply black bryony to the skin for bruises, strains, torn muscles, gout, and pain, but there is no good scientific evidence to support these uses. It has been used as a poultice for bruises and inflamed joints.

\section{CONCLUSIONS}

Plant poisoning can be considered a public health problem. Intoxication by toxic plants are a significant cause of morbidity and mortality, which in most cases are accidental intoxications, therefore may be avoidable. Many species of toxic plants have been reported from different plant families. Mostly the poisonous parts of toxic plants have been reported to be seeds, latex, root, root bark, fruits, stem, stem bark, tubers, bulbs and sometimes whole plant.

This review article dealt with 12 poisonous angiosperm plant species belonging to eight different families. The general characteristics of these plant species, etymology, their toxicity, symptoms and medicinal uses/properties are discussed. The data regarding family of poisonous plants, its poisonous part and its active chemical constituents can also be used in the classification of poisonous plants. Some plants cause poisoning to both human beings as well as livestock population, while some cause poisoning to humans only. The poisonous nature of a plant/part depends mainly on the quantity consumed. In small quantity, the poison can exhibit its therapeutic value while in higher quantity, show its toxic effects.

There are many plants which have no medicinal value and not used for edible purpose but which are at times ingested through oversight, particularly by children. Many of these are responsible for poisoning in cattle. Some of the plants have been used for the poisoning purposes and for committing suicide. There are some plants like Cerbera odollum, Cascabela thevetia, Abrus precatorius and Datura stramonium which are very toxic and used for homicidal and suicidal purposes. Almost no other plant has such a history of crime as Datura and the seeds are favorite poisons. On the basis of plant origin and toxicity, the forensic team can tell whether it is a suicide, homicide or accident.

The significance of the wild poisonous plants for their toxicological and medicinal value (economic) cannot be overrated. On one hand, these plants may cause serious health problems and sometimes death, yet on the other hand, many of them in regulated doses may act as effective remedies for amelioration of diseases. This review study concludes that poisonous plants have medicinal properties for mankind. With certain precautions, these toxic plants can be used for medicinal purposes. Scientific evidence to recommend the use of these poisonous plants in its natural form is insufficient, but some of its components, when purified can be used for medicinal purposes. The knowledge about toxic plants is still insufficient. Additional efforts are needed to both deepen research and understanding of these properties and how they can be countered with antidotes or used as part of herbal medicines in the right proportions. Spreading word and awareness about the properties of these plants among populations is also of paramount importance.

In conclusion, the aim of the present review is to emphasize that accidental ingestion of some plants in our environment which may even closely resemble other edible plants may cause serious poisoning, sometimes fatal. As these poisonous plants have some medicinal properties, these can be grown in containment facilities which can avoid unnecessary contact by human and cattle.

\section{ACKNOWLEDGEMENTS}

The author wishes to thank Dr. E.V.S. Prakasa Rao, retired scientist, Central Institute of Medicinal and Aromatic Plants (CIMAP), Bangalore Division, for discussions on the medicinal aspects of plants. The author also thanks Professor Radha Prasanna, Division of Microbiology, Indian Agriculture Research Institute (IARI), New Delhi, for providing inspiration behind this work.

\section{DECLARATIONS}

\section{Funding}

- The authors did not receive support from any organization for the submitted work.

- No funding was received to assist with the preparation of this manuscript.

- No funding was received for conducting this study.

- No funds, grants, or other support was received.

\section{Conflicts of Interest/Competing Interests}

- The authors have no relevant financial or non-financial interests to disclose.

- The authors have no conflicts of interest to declare that are relevant to the content of this article.

- All authors certify that they have no affiliations with or involvement in any organization or entity with any financial interest or non-financial interest in the subject matter or materials discussed in this manuscript.

The authors have no financial or proprietary interests in any material discussed in this article. 


\section{Ethical Responsibilities of Authors}

- The manuscript is neither published in any journal nor submitted to any journal for publication.

The submitted review article is original and is not published elsewhere in any form or language (partially or in full), unless the new work concerns an expansion of previous work. (Please provide transparency on the re-use of material to avoid the concerns about text-recycling ('self-plagiarism').

No software used in the present review study.

\section{REFERENCES}

Adriana, K. F., Peter, Z., Istvan, R., Borbala, F., Gyorgy, S., \& Judit, H. (2007). Phenanthrenes and a dihydrophenanthrene from Tamus communis and their cytotoxic activity. Phytochemistry, 68(5), 687-691. https:// doi.org/10.1016/j.phytochem.2006.10.028

Bandara, V., Weinstein, S. A., White, J., \& Eddleston, M. (2010). A review of the natural history, toxinology, diagnosis and clinical management of Nerium oleander (common oleander) and Thevetia peruviana (yellow oleander) poisoning. Toxicon, 56(3), 273-281. https://doi. org/10.1016/j.toxicon.2010.03.026

Bose, T. K., Basu, R. K., Biswas, B., De, J. N., Majumdar, B. C., \& Datta, S. (1999). Cardiovascular effects of yellow oleander ingestion. Journal Indian Medical Association, 97(10), 407-410.

Chopra, R. N., Badhwar, R. L., \& Ghosh, S. (1949). Poisonous plants of India. Vol. I. Indian Council of Agricultural Research (ICAR), New Delhi.

Davis, T. Z., Stegelmeier, B. L., Lee, S. T., Green, B. T., \& Chitko-McKown, C. G. (2018). Effect of grinding and long-term storage on the toxicity of white snakeroot (Ageratina altissima) in goats. Research in Veterinary Science, 118, 419-422. https://doi.org/10.1016/j.rvsc.2018.04.006

Eddleston, M., \& Warrell, D. A. (1999). Management of acute yellow oleander poisoning. OJM: An International Journal of Medicine, 92(9), 483-485. https://doi.org/10.1080/15563650902824001

Eddleston, M., Rajapakse, S., Rajakanthan, Jayalath, S., Sjöström, L., Santharaj, W., Thenabadu, P. N., Sheriff, M. H., \& Warrell, D. A. (2000). Anti-digoxin Fab fragments in cardiotoxicity induced by ingestion of yellow oleander: a randomised controlled trial. Lancet (London, England), 355(9208), 967-972. https://doi.org/10.1016/ s0140-6736(00)90014-x

Ferah, A. U., Dilek, M. O., Ercument, Y., \& Oktay, D. (2006). Hemlock poisoning (case report): die like Socrates. Resuscitation, 70(2), 337. https://doi.org/10.1016/j.resuscitation.2006.06.125

Gaillard, Y., Krishnamoorthy, A., \& Bevalot, F. (2004). Cerbera odollum: a 'suicide tree' and cause of death in the state of Kerala, India. Journal of Ethnopharmacology, 95(2-3), 123-126. https://doi.org/10.1016/j. jep.2004.08.004

Glatstein, M., Alabdulrazzaq, F., \& Scolnik, D. (2016). Belladonna Alkaloid Intoxication: The 10-Year Experience of a Large Tertiary Care Pediatric Hospital. American Journal of Therapeutics, 23(1), e74-e77. https:// doi.org/10.1097/01.mjt.0000433940.91996.16

Gledhill, D. (2008). The Names of Plants. Cambridge University Press. ISBN 9780521866453 (hardback), ISBN 9780521685535 (paperback). pp. 39,44

Gupta, V. K., \& Sharma, B. (2017). Forensic Applications of Indian Traditional Toxic Plants and their Constituents. Forensic Research \& Criminology International Journal, 4(1), 27-32. https://doi.org/10.15406/ frcij.2017.04.00101

Gupta, R., Kachhawa, J. B., Gupta, R. S., Sharma, A. K., Sharma, M. C., \& Dobhal, M. P. (2011). Phytochemical evaluation and antispermatogenic activity of Thevetia peruviana methanol extract in male albino rats. Human Fertility, 14(1), 53-59. https://doi.org/10.3109/14647273.20 10.542230

Hahn, R., \& Nahrstedt, A. (1993). Hydroxycinnamic Acid Derivatives, Caffeoylmalic and New Caffeoylaldonic Acid Esters, from Chelidonium majus. Planta Medica, 59(1), 71-75. https://doi. org/10.1055/s-2006-959608

Harrison, J. B. (1872). The effects of Belladonna plaster. The British Medical Journal, 1(594), 520-521.
Jang, D. H., Hoffman, R. S., \& Lewis, L. S. (2010). Attempted suicide, by mail order: Abrus precatorius. Clinical Toxicology. Conference: 2010 International Congress of the European Association of Poisons Centres and Clinical Toxicologists Bordeaux France. Conference Publication: (var. pagings), 48(3), 308.

Kannan, R. (1991). Koels feeding on the yellow oleander. Blackbuck, $7(2), 48$.

Kareru, P. G., Keriko, J. M., Kenji, G. M., \& Gachanja, A. N. (2010). Antitermite and antimicrobial properties of paint made from Thevetia peruviana (Pers.) Schum. oil extract. African Journal of Pharmacy and Pharmacology, 4(2), 87-89.

Khajja, B. S., Sharma, M., Singh, R., \& Mathur, G. K. (2011). Forensic study of Indian toxicological plants as botanical weapon (BW): A review. Journal Environment \& Analytic Toxicology, 1(4), 112-116. https://doi. org/10.4172/2161-0525.1000112

Kingsbury, J. M. (1994). Common Poisonous Plants. Information Bulletin 104. A Cornell Cooperative Extension Publication. United States Department of Agriculture (USDA), pp. 1-30.

Konca, C., Kahramaner, Z., Bosnak, M., \& Kocamaz, H. (2016). Hemlock (Conium maculatum) poisoning in a child. Turkish Journal of Emergency Medicine, 14(1), 34-36. https://doi.org/10.5505/1304.7 361.2013 .23500

Krishnan, M. (1952). "Koels (Eudynamis scolopaceus) eating the poisonous fruit of the Yellow Oleander". Journal of the Bombay Natural History Society, 50(4), 943-945.

Kohls, S., Scholz-Böttcher, B. M., Teske, J., Zark, P., \& Rullkötter, J. (2012). Cardiac glycosides from Yellow Oleander (Thevetia peruviana) seeds. Phytochemistry, 75, 114-27. https://doi.org/10.1016/j. phytochem.2011.11.019

Krenzelok, E.P., Jacobsen, T. D., \& Aronin, J. M. (1996). Hemlock ingestions: The most deadly plant exposures. Journal of Toxicology: Clinical Toxicology, 34, 601-602.

Launert, E. (1981). Guide to Edible and Medicinal Plants. Hamlyn Publishing Group Limited, United Kingdom.

Lee, M. R. (2007). Solanaceae IV: Atropa belladonna, deadly nightshade. The Journal of the Royal College of Physicians Edinburgh, 37(1), 77-84.

Leete, E. B. (1994). Becoming a hospice volunteer. American Journal of Hospice \& Palliative Medicine, 11, 27-32.

Mateo, M. A., Mavrakanas, N., \& Schutz, J. S. (2009). Acute anticholinergic syndrome from Atropa belladonna mistaken for blueberries. European Journal of Ophthalmology, 19(1), 170-172. https://doi. org/10.1177/112067210901900130

Menon, M. S. (2016). Clinical profile and management of poisoning with suicide tree: An observational study. Heart Views, 17(4), 136-139. https://doi.org/10.4103/1995-705X.201783

Monier-Williams, M. (1899). A Sanskrit-English dictionary: etymologically and philologically arranged with special reference to cognate IndoEuropean languages. Oxford: Clarendon Press.

Neelakantan, K. K. (1953). Common Grey Hornbill (Tockus birostris) eating fruits of the Yellow Oleander (Thevetia neriifolia). Journal of the Bombay Natural History Society, 51(3), 738.

Niering, W. A., \& Olmstead, N. C. (1985). The Audubon Society Field Guide to North American Wildflowers, Eastern Region. Knopf. p. 380.

Parsons, W. T., \& Cuthbertson, E. G. (1992). Noxious Weeds of Australia. Melbourne, Australia: Inkata Press, pp. 692.

Peter, C. (1989). Toxicants of Plant Origin: Alkaloids. Vol. 1 (1 $1^{\text {st }}$ Edition). Boca Raton, Florida: CRC Press., p. 118.

Quattrocchi, U. (1999). CRC World Dictionary of Plant Names: Common Names, Scientific Names, Eponyms, Synonyms, and Etymology. CRC Press.

Raetsch, Ch. (2005). The encyclopedia of psychoactive plants: ethnopharmacology and its applications. US: Park Street Press. pp. 80-85.

Rafael, M., Barros, L., Carvalho, A. M., \& Ferreira, I. C. F. R. (2011). Topical anti-inflammatory plant species: Bioactivity of Bryonia dioica, Tamus communis and Lonicera peryclimenum fruits. Industrial Crops and Products, 34(3), 1447-1454.

Raj, P. J. S. (1959). Birds eating poisonous fruit of Yellow Oleander (Thevetia neriifolia). Journal of the Bombay Natural History Society, 56(3), 639.

Raj, P. J. S. (1963). Additions to the list of birds eating the fruit of Yellow Oleander (Thevetia neriifolia). Journal of the Bombay Natural History Society, 60(2), 457-458.

Rajapakse, S. (2009). Management of yellow oleander poisoning. 
Clinical Toxicology, 47(3), 206-212. https://doi.org/10. 1080/15563650902824001

Rajasingh, S. G., \& Rajasingh, I. V. (1971). Birds and mammals eating the fruits of Yellow Oleander (Thevetia peruviana). Journal of the Bombay Natural History Society, 67(3), 572-573.

Reynolds, T. (2005). Hemlock alkaloids from Socrates to poison aloes. Phytochemistry, 66, 1399 - 1406. https://doi.org/10.1016/j. phytochem.2005.04.039

Rita, S. (2018). Toxic plants: Knowledge, medicinal uses and potential human health risks. Environment and Ecology Research, 6(5), 487492. https://doi.org/10.13189/eer.2018.060509

Rizzi, D., Basile, C., Di Maggio, A., Sebastio, A., Introna, F., \& Rizzi, R. Jr. (1991). Clinical spectrum of accidental hemlock poisoning: neurotoxic manifestations, rhabdomyolysis and acute tubular necrosis. Nephrology Dialysis Transplantation, 6, 939-943. https:// doi.org/10.1093/ndt/6.12.939

Roberts, M. F., \& Wink, M. (1998). Alkaloids biochemistry, ecology, and medicinal applications. New York: Plenum Press. pp. 18.

Roberts, D. M., Southcott, E., Potter, J. M., Roberts, M. S., Eddleston, M., \& Buckley, N. A. (2006). Pharmacokinetics of digoxin cross-reacting substances in patients with acute yellow oleander (Thevetia peruviana) poisoning, including the effect of activated charcoal. Therapeutic Drug Monitoring, 28(6), 784-792. https://doi.org/10.1097/ FTD.0b013e31802bfd69

Rogelj, B., Popovic, T., Ritonja, A., Strukelj, B., \& Brzin, J. (1998). Chelidocystatin, a novel phytocystatin from Chelidonium majus. Phytochemistry, 49(6), 1645-1649. https://doi.org/10.1016/s00319422(98)00281-7

Rupesh, J., Savita, Y., Ronak, K., Kehar, D., Mithun, B., \& Jagdish, R.
(2017). Pharmacognostial Evaluation and Phytochemical Screeing of Thevetia peruviana. Journal of Drug Delivery \& Therapeutics, 7(1), 60-64. https://doi.org/10.22270/jddt.v7i1.1378

Singh, S., Singh, T. D., Singh, V. P., \& Pandey, V. B. (2010). Quaternary Alkaloids of Argemone mexicana. Pharmaceutical Biology, 48(2), 158-160. https://doi.org/10.3109/13880200903062622

Soni, P., Siddiqui, A. A., Dwivedi, J., \& Soni, V. (2012). Pharmacological properties of Datura stramonium L. as a potential medicinal tree: An overview. Asian Pacific Journal of Tropical Biomedicine, 2(12), 10021008. https://doi.org/10.1016/S2221-1691(13)60014-3

Tewari, D., Mocan, A., Parvanov, E. D., Sah, A. N., Nabavi, S. M. Huminiecki, L., Ma, Z. F., Lee, Y. Y., Horba-czuk, J. O., \& Atanasov, A. G. (2017). Ethnopharmacological Approaches for Therapy of Jaundice: Part I. Frontiers in Pharmacology, 8, 518. https://doi.org/10.3389/ fphar.2017.00518

Ulbricht, C., Basch, E., Hammerness, P., Vora, M., Wylie, J. Jr., \& Woods, J. (2004). An evidence-based systematic review of belladonna by the natural standard research collaboration. Journal of Herbal Pharmacotherapy, 4(4), 61-90.

World Health Organization (WHO/UNICEF). (2008). World report on child injury prevention. Peden, M., Oyegbite, K., Ozanne-Smith, J., Hyder, A. A., Branche, C., Rahman, A. K. M. F., Rivara, F., \& Bartolomeos, K. (Editors). WHO Press, Switzerland.

Willcox, M. L., Graz, B., Falquet, J., Sidibe, O., Foster, M., \& Diallo, D. (2007). Argemone mexicana Decoction for the Treatment of Uncomplicated Falciparum Malaria. Transactions of the Royal Society of Tropical Medicine and Hygiene, 101(12), 1190-1198. https://doi.org/10.1016/j. trstmh.2007.05.017 